\title{
Feline histoplasmosis: a case of supraorbital involvement ${ }^{*}$ Histoplasmose felina: relato de caso com envolvimento supraorbital
}

\author{
Elaine Waite de Souza, ${ }^{* *}$ Isabella D. F. Gremião, ${ }^{* *}$ Sandro Antonio Pereira, ${ }^{* *}$ Simone Carvalho dos Santos Cunha, ${ }^{* * *}$ \\ Cintia de Moraes Borba****
}

\begin{abstract}
Histoplasmosis is a systemic fungal infection caused by the dimorphic fungus Histoplasma capsulatum that infects humans and a wide variety of mammalian species, including cats. In Brazil only four cases of this disease were reported in domestic cats. The present study reports a case of an indoor cat, rescued from street three years ago, that developed histoplasmosis with supraorbital involvement. The cat presented sneezing, dyspnea and increased respiratory sounds and the diagnosis suspected was allergic rhinitis. Prednisolone and amoxicillin were prescribed. The patient returned to clinic after clinical signs worsened with a swelling of the right supraorbital region, unilateral left side conjunctivitis and enlarged submandibular lymph nodes. Cytology and culture revealed Histoplasma capsulatum. Initially, itraconazole $(10 \mathrm{mg} / \mathrm{Kg}$ SID orally) was prescribed and due to the worsening of clinical signs, was combined amphotericin B $(0.5 \mathrm{mg} / \mathrm{kg} \mathrm{SC})$ for two weeks. The therapy with amphotericin was discontinued and itraconazole continued to be administered for six months. The clinical signs were resolved and no recrudescence was reported. It is important that veterinary practitioners to be aware of the clinical features of feline histoplasmosis and consider the possibility of a subclinical infection.
\end{abstract}

Keywords: corticosteroid, cat, involvement supraorbital, Histoplasma capsulatum.

\section{Resumo}

Histoplasmose é uma infecção sistêmica causada pelo fungo dimórfico Histoplasma capsulatum, que infecta humanos e uma ampla variedade de mamíferos, incluindo os gatos. No Brasil, somente quatro casos dessa doença foram relatados em gatos domésticos. O presente estudo relata um caso de um gato, vivendo em ambiente domiciliar sem acesso à rua, mas que tinha sido resgatado das ruas havia três anos, que desenvolveu histoplasmose com envolvimento supraorbital. O paciente apresentava espirros, dispneia e aumento dos sons respiratórios e a suspeita clínica foi rinite alérgica. O animal foi tratado com prednisolona e amoxicilina. Com a piora dos sinais clínicos o paciente retornou apresentando um edema na região supraorbital direita, conjuntivite unilateral do olho esquerdo e linfoadenomegalia na região submandibular. A citologia e a cultura revelaram a presença de Histoplasma capsulatum. Inicialmente, itraconazol (10 mg/kg via oral, uma vez ao dia) foi prescrito e devido à piora dos sinais clínicos, anfotericina B $(0,5 \mathrm{mg} / \mathrm{Kg}$ via subcutânea) foi administrada por duas semanas associada ao triazólico. A terapia com anfotericina B foi descontinuada e o itraconazol mantido por seis meses até a cura clínica e nenhuma recrudescência foi registrada. É importante ressaltar que veterinários devem estar atentos para os sinais clínicos da histoplasmose e que devem considerar a possibilidade de uma infecção subclínica.

Palavras-chave: corticoide, gato, envolvimento supraorbital, Histoplasma capsulatum.

\section{Introduction}

Histoplasmosis is a systemic fungal infection caused by the dimorphic fungus Histoplasma capsulatum, which has a worldwide distribution in temperate and subtropical climates and infects humans and a wide variety of mammalian species (Horwath et al., 2015).

Most of the endemic areas can be found in the United States, with highest prevalence in the Midwestern and Southern states and regions along the Ohio, Missouri, and Mississippi Rivers (Brömel e Sykes, 2005; Nett et al., 2015). In Brazil, several micro-epidemics have been reported in people living in the Brazilian states of Rio de Janeiro, São Paulo, Minas Gerais,
Paraíba, Bahia and Amazonas (Zancopé-Oliveira et al., 2005; Passos et al., 2014; Rocha-Silva et al., 2014). In relation to feline histoplasmosis little information is available in this country. Only four cases of this disease were reported in domestic cats (Carneiro et al., 2005; Brilhante et al., 2012).

The possible sources of exposure to Histoplasma sp. spores for animals, especially cats, are digging in outside soil, bats around the house, indoor potted plants and unfinished basements (Reinhart et al., 2012).

The fungus infect hosts by inhalation and possibly by ingestion of conidia from the mycelial phase, which then convert to the yeast phase in the lungs and thoracic lymph nodes. The yeast cells

${ }^{*}$ Recebido em 4 de agosto de 2014 e aceito em 16 de junho de 2015.

**Laboratório de Pesquisa Clínica em Dermatozoonoses, Instituto Nacional de Infectologia, Fundação Oswaldo Cruz (Fiocruz), Av Brasil, 4365 - Manguinhos, 21045-900, Rio de Janeiro - RJ, Brazil.

${ }^{* * *}$ Faculdade de Medicina Veterinária, Universidade Federal Fluminense (UFF), Rua Miguel de Frias, 9, Icaraí, 22220-900, Niterói - RJ, Brazil.

****Laboratório de Taxonomia, Bioquímica e Bioprospecção de Fungos Instituto Oswaldo Cruz, Fundação Oswaldo Cruz (Fiocruz), Av Brasil, 4365 Manguinhos, 21045-900, Rio de Janeiro - RJ, Brazil.

Autor para correspondência: Elaine Waite de Souza - esewaite@gmail.com. 
proliferate within macrophages and are transported to systemic organs by a mononuclear phagocytic system (Atiee et al., 2014; Kobayashi et al., 2009).

Clinical signs may include cough, dyspnea, exercise intolerance, weight loss, lymphadenopaty, fever and others (Reinhart et al., 2012). The organs most commonly affected in cats are lungs, liver, lymph nodes, eyes, and bone marrow (Brömel e Sykes, 2005). Skin lesions in animals are not common (Raskin, 2001).

The diagnosis of histoplasmosis is made based on clinical signs, radiographic abnormalities, cytology and histopathology methods (Clinkenbeard et al., 1987; Brömel e Sykes 2005). Growth of the mycelial phase of Histoplasma on culture for identification is not the first choice because of the risk of infection of laboratory personnel (Brömel e Sykes 2005).

The present study reports a case of indoor cat that developed histoplasmosis with supraorbital involvement three years after rescued from street.

\section{Case report}

A three-year old, mixed breed, female and spayed indoor cat, weighing $3 \mathrm{Kg}$, vaccinated against rhinotracheitis, calicivirosis and panleukopenia was taken to a private veterinary clinic in Rio de Janeiro, Brazil, with a history of sneezing, dyspnea and increased respiratory sounds. The clinical examination revealed normothermia, normal mucosal color, hyperemia in the left nostril and a loud inspiratory noise; no alterations were found in abdominal palpation. A thoracic radiograph was requested but it was refused by the owner. Prednisolone $(1 \mathrm{mg} / \mathrm{kg}$ SID orally in five days) and amoxicillin (20 mg/kg bid orally in ten days) were prescribed. The diagnosis suspected was allergic rhinitis.

After fifteen days, the cat was brought back for consultation with mild dyspnea, apparent fatigue, loss of appetite and dysphagia. Moreover, it was noted that there was a swelling of the right supraorbital region (Figure 1A), unilateral left sided conjunctivitis and enlarged submandibular lymph nodes. At this point, blood was collected for complete blood count and renal function test. Fine needle aspiration cytology of the supraorbital nodule was performed and a thorax and skull radiography was requested. The complete blood count result revealed monocytosis, the thoracic radiographys were within normal limits and the skull radiography showed increased radiopacity in the soft tissue adjacent to the right orbit. Cytology examination showed mixed

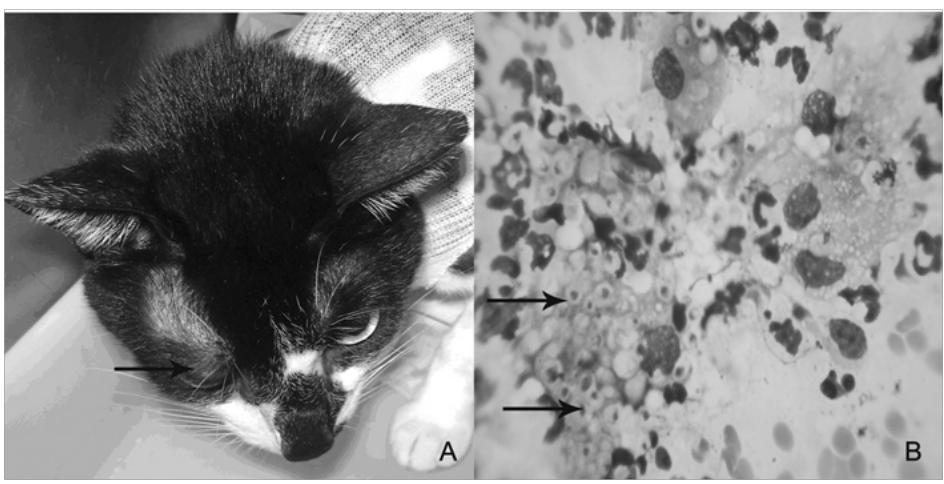

Figure 1: (A) Edema in the right supraorbital region (arrow). (B): Photomicrograph of cytological examination. Yeast-like cells of Histoplasma capsulatum are seen in macrophages (arrow). Romanowsky staining, magnification: 1000X. inflammatory cells, with predominance of intact neutrophils, presence of reactive macrophages that phagocytosed yeast-like organisms (Figure 1B) and rare plasmocytes. Based on these results, a new aspirate was performed in the supraorbital nodule and a sample was obtained for fungal culture. Itraconazole (10 $\mathrm{mg} / \mathrm{kg}$ SID orally) was prescribed. The result revealed Histoplasma capsulatum.

Clinical signs worsened, after three days, the sneezing became more frequent, nodule size increased and there was regurgitation after force-feeding. A feeding tube was inserted and metoclopramide was prescribed $(0.3 \mathrm{mg} / \mathrm{kg}$ subcutaneouslySC-BID). Additionally, serum concentrations of alanine aminotransferase and alkaline phosphatase were measured and results were within the normal limits. Itraconazole was continued and a high-calorie wet food was administered via feeding tube. After seven days, due to the worsening of clinical signs, a therapy was started with amphotericin B $(0.5 \mathrm{mg} / \mathrm{kg}$ SC diluted in $200 \mathrm{~mL}$ of $0.45 \% \mathrm{NaCl} / 2.5 \%$ glucose, three times a week for two weeks). Itraconazole (via feeding tube) and metoclopramide SC were continued. On the days when amphotericin B was not administered, a Ringer-Lactate solution (150 $\mathrm{mL}$ ) was applied subcutaneously to increase renal perfusion and decrease the nephrotoxicity caused by this drug. Serum creatinine concentrations were monitored weekly, but showed no alterations during the treatment. After two weeks, there was an improvement, as the supraorbital nodule decreased in size, sneezing was less frequent and appetite increased gradually.

Therapy with amphotericin B was discontinued, and itraconazole continued to be administered by a feeding tube along with food. After four months, the supraorbital nodule completely disappeared, so did the sneezing and dysphagia. Treatment with itraconazole continued for more two months, and the total time of the antifungal treatment was six months. There was no recurrence of the disease for 6 months at last follow-up.

\section{Discussion}

Feline histoplasmosis is the second most common fungal disease reported in cats, mainly in young cats, after cryptococcosis in USA (Atiee et al., 2015).

Systemic fungal infections typically occur in specific geographic areas. Therefore, suspicions of some infections are related to a history of travel to endemic regions (Johnson et al., 2004). The female cat referred to in this case lived in an apartment since it was rescued from street when it was kitten. It was not possible to determine how the infection occurred, but it is acceptable that this cat was in contact with sources of exposure to Histoplasma capsulatum. spores. According to Clinkenbeard et al. $(1987,1988)$, a clinically inapparent infection of the lungs and their associated lymph nodes by $H$. capsulatum occurs commonly in cats and dogs residing in Histoplasma-endemic areas. As far as we know, no data is currently available how long a cat may have a subclinical infection. Therefore, it is not possible to affirm that the cat studied here had a subclinical infection, but it should be considered.

Pathogenesis of histoplasmosis may suggest that outdoor cats have a higher risk for developing disease because of exposure to contaminated soil, but infection in strictly indoor animals has been reported and related to potted plants (Reinhart et al., 2012). 
The incubation period of histoplasmosis ranges from 12 to 16 days (Taboada, 2005). As the infection becomes active, the disease can spread to any organ, most commonly lungs, gastrointestinal tract, spleen, liver, bone marrow, eyes and adrenals (Kerl, 2003). Different forms of histoplasmosis, as pulmonary, disseminated, primary gastrointestinal, have been reported in cats (Aulakh et al., 2012). Sometimes the skin is also affected (Fischer et al., 2013).

Cats with histoplasmosis normally present anaemia, weight loss, lethargy, fever, anorexia, and interstitial lung disease, but some cases without involvement of the respiratory tract have been reported (Fischer et al., 2013). Less frequent clinical signs include vomiting, diarrhea, blindness and lameness (Brömel e Sykes, 2005; Aulakh et al., 2012). In the present case, initially, the cat presented clinical signs as sneezing, dyspnea and increased respiratory sounds allowing the diagnosis of allergic rhinitis. There was no fever, weight loss or other significant signs.

After, with the worsening of health of the animal described here, and evidence of a swelling of the right supraorbital region, unilateral left sided conjunctivitis and enlarged submandibular lymph nodes, new tests were made suggesting that the cat had a histoplasmosis confirmed by fungal culture besides the thoracic radiography did not show abnormal results.

Thus, it is possible to speculate that the cat in this case may have had subclinical histoplasmosis for some time which became more apparent following administration of corticosteroids. The steroid immunosupression dose for cats is considered a range from 2,2 $\mathrm{mg}$ to $6,6 \mathrm{mg} / \mathrm{kg}$ (Ferguson e Hoenig, 1995), and the cat in this present case received a dose of $1 \mathrm{mg} / \mathrm{kg}$. Therefore, we have to consider the possibility of worsening of clinical signs has been related to the steroids. In general, cats tolerate glucocorticoids well, and adverse effects seem to occur less frequently in cats than in other species (Lowe, 2010).

More severe infections can occur in individuals with impaired immune systems or if the dose of infective spores is high (Brömel e Greene, 2012). Cutaneous lesions as part of disseminated histoplasmosis in humans infected with the human immunodeficiency virus that developed acquired immune deficiency syndrome has been described (Ramdial et al., 2002). Although the cat in this report had not been tested to feline leukemia virus or feline immunodeficiency virus it is important to emphasize that defects in immune response may have an important component in the development of this cat's disease.

Hematological findings in cat's histoplasmosis indicated neutropenia, thrombocytopenia, anemia or any combination of those alterations (Davies e Troy, 1996; Reinhart et al., 2012). In this report the only abnormality found was monocytosis, one of the most common hematological changes in dogs and cats histoplasmosis (Brömel e Sykes, 2005).

\section{References}

ATIEE, G.; KVITKO-WHITE, H.; SPAUDING, K.; JOHNSON, M. Ultrasonographic appearance of histoplasmosis identified in the spleen in 15 cats. Veterinary Radiology Ultrasound, v. 55, n.3, p. 310-314, 2014.
Cytology and histopathology methods are commonly used in veterinary medicine for diagnosing histoplasmosis (Clinkenbeard et al., 1987), but the definitive diagnosis is established by culture (Kumar et al., 2005). In our case the cytology was import because it identified yeast like cells inside macrophages indicating histoplasmosis. The final diagnosis was done after culturing the sample from supraorbital nodule aspirate using properly biosafety conditions (Fiocruz, 2005). It is necessary to emphasize the potential risks for laboratory personnel to exposure to infective conidia. Serology was not performed in this report. According to Cook et al. (2012) serologic tests for antibodies against Histoplasma capsulatum . are generally regarded as an unreliable way to identify infected cats, with a risk of false-negative results in patients with active disease.

The histoplasmosis safest diagnosis is histopathology and it is possible to distinguish fairly well fungal cells from Histoplasma, Cryptococcus, Sporothrix, Coccidioides, among others, considering the morphology (size, shape, cell wall) and the distribution of the lesions (Kobayashi et al., 2009). The differential diagnosis is very important and should be considered to cryptococcosis, a mycosis of larger incidence in USA and respiratory tract diseases (Davies e Troy, 1996) and sporotrichosis, due to the occurrence of an epidemic in Rio de Janeiro since 1998 (Schubach et al., 2004).

Itraconazole has been reported to be the drug of choice for the treatment of feline histoplasmosis (Johnson et al., 2004; Vinayak et al., 2007). However, in our case the expected clinical response was not observed. Hence, we chose to combine amphotericin in the treatment since combined antifungal drugs can be more effective (Powers, 2004; Lloret et al., 2013). Although the majority of cats treated today for histoplasmosis receive azole drugs as a first line of therapy, other antifungal drugs, only or combined, may have a role in optimized treatment (Reinhart et al., 2012). The subcutaneous route for the treatment with amphotericin $B$ in our case was preferred for being less nephrotoxic (O'Brien et al., 2006). The cat treated here was monitored, it did not present side effects during the treatment, the clinical signs were resolved and no recrudescence was reported until now.

\section{Conclusion}

We presented the data of a feline disease considering the importance of histoplasmosis for Veterinary Mycology as well as the scarcity of case reports in cats in Brazil.

Histoplasmosis in cats has not been described with frequency in Brazil and with supraorbital involvement is the first case reported. Thus, it is very important that veterinary practitioners to be aware of the clinical features of feline histoplasmosis and should consider the possibility of a subclinical infection when a patient have had an outdoor lifestyle. It is also important the differential diagnosis because immunosuppressive drugs can cause the onset of severe signs in subclinical patients, proving to be a predisposing factor for disease development.

AULAKH, H.K.; AULAKH, K.S.; TROY, G.C. Feline Histoplasmosis: A retrospective study of 22 cases (1986-2009). Journal of American Animal Hospital Association, v. 48, n.3, p. 182-187, 2012. 
BRILHANTE, R.S.N.; COELHO, C.G.V.; SIDRIM, J.J.C.; LIMA, R.A.C.; RIBEIRO, J.F.; CORDEIRO, R.A.; CASTELO-BRANCO, D.S.C.M.; GOMES, J.M.F.; SIMÕES-MATTOS, L.; MATTOS, M.R.F.; BESERRA, H.E.O.; NOGUEIRA, G.C.; PINHEIRO, A.Q.; ROCHA, M.F.G. Feline Histoplasmosis in Brazil: clinical and laboratory aspects and a comparative approach of published reports. Mycopathologia, v. 173, p. 173-193, 2012.

BRÖMEL, C.; SYKES, J.E. Histoplasmosis in dogs and cats. Clinical Techniques in Small Animal Practice, v. 20, p. 227-232, 2005.

BRÖMEL, C.; GREENE, C.E. Histoplasmosis. In: GRENNE, C.E. (Ed.) Infectious Diseases of the Dog and Cat. 4th ed. Philadelphia (PA): Saunders Elsevier, 2012, p. 614-621.

CARNEIRO, R.A.; LAVALLE, G.E.; ARAÚJO, R.B. Histoplasmose cutânea em gato: relato de caso. Arquivo Brasileiro de Medicina Veterinária e Zootecnia, v. 57, p. 158-161, 2005.

CLINKENBEARD, K.D.; COWELL, R.L.; TYLER, R.D.

Disseminated histoplasmosis in cats: 12 cases (1981-1986).

Journal of the American Veterinary Medical Association, v. 190, n.11, p. 1445-1448, 1987.

CLINKENBEARD, K.D.; COWELL, R.L.; TYLER, R.D. Disseminated histoplasmosis in dogs: 12 cases (1981-1986). Journal of the American Veterinary Medical Association, v. 193, n.11, p. 1443-1447, 1988.

COOK, A.K.; CUNNINGHAM, L.Y.; COWELL, A.K.; JOSEPH, L. Clinical evaluation of urine Histoplasma capsulatum antigen measurement in cats with suspected disseminated histoplasmosis. Journal of Feline Medicine and Surgery, v. 14, p. 512-515, 2012.

DAVIES, C.; TROY, G.C. Deep mycotic infections in cats. Journal American Animal Hospital Association, v. 32, p. 380-391, 1996.

FERGUSON, D.C.; HOENIG, M. Glucocorticoids,

mineralocorticoids and steroid synthesis inhibitors. In: $\mathrm{H}$. Richard Adams. Veterinary Pharmacology and Therapeutics, 7th ed. Ames, lowa: lowa State University Press, 1995. p. 622-643.

FIOCRUZ. Procedimentos para a manipulação de microrganismos patogênicos e/ou recombinantes na Fiocruz. Rio de Janeiro, RJ: Ministério da Saúde, 2005, 219 p.

FISCHER, N.M.; FAVROT, C.; MONOD, M.; GREST, P.; RECH, K.; WILHELM, S. A case in Europe of feline histoplasmosis apparently limited to the skin. Veterinary Dermatology, v. 23, p. 1-5, 2013.

HORWATH, M.C.; FECHER, R.A.; DEEPE, G.S.JR. Histoplasma capsulatum, lung infection and immunity. Future Microbiology, v.10, p. 967-975, 2015.

JOHNSON, L.R.; FRY, M.M.; ANEZ, K.L.; PROCTOR, B.M.; JANG, S.S. Histoplasmosis infection in two cats from California. Journal American Animal Hospital Association, v. 40, n. 2, p. 165169, 2004.

KERL, M.E. Update on canine and feline fungal disease. The Veterinary Clinics North American Small Animal Practice, v. 33, n. 3, p. 721-747, 2003.

KOBAYASHI, R.; TANAKA, F.; ASAI, A.; KAGAWA, Y.; IKEDA, T.; SHIROTA, K. First case report of histoplasmosis in a cat in Japan. Journal Veterinary Medical Science, v. 71, n.1, p. 16691672, 2009.

KUMAR, V.; ABBAS, A.K.; FAUSTO, N. Robbins \& Cotran Patologia: Bases Patológicas das Doenças, $7^{\mathrm{a}}$ ed. Rio de Janeiro: Elsevier, 2005. p. 792-793.
LLORET, A.; HARTMANN, K.; PENNISI, M.G.; FERRER, L.; ADDIE, D.; BELÁK, S.; BOUCRAUT-BARALON, C.; EGBERINK, H.; FRYMUS, T.; GRUFFYDD-JONES, T.; HOSIE, M.J., LUTZ, H.; MARSILIO, F.; MOSTL, K.; RADFORD, A.D.; THIRY, E.; TRUYEN, U.; HORZINEK, M.C. Rare systemic mycoses in cats: blastomycosis, histoplasmosis and coccidioidomycosis - ABCD guidelines on prevention and management. Journal of Feline Medicine and Surgery, v. 15, p. 624-627, 2013.

LOWE, A. Glucocorticoid use in cats. Veterinary Medicine 2010 $\mathrm{http}: / / v e t e r i n a r y m e d i c i n e . d v m 360 . \mathrm{com} /$ vetmed/article/articleDetail.js p?id=656964\&sk=\&date=\&pagelD=2 Accessed in February 2014.

NETT, R.J.; SKILLMAN, D.; RIEK, L.; DAVIS, B.; BLUE, S.R.; SUNDBERG, E.E.; MERRIMAN, J.R.; HAHN, C.G.; PARK, B.J. Histoplasmosis in Idaho and Montana, USA, 2012-2013. Emerging Infectious Diseases, v. 21(6), p. 1071-1072, 2015.

O'BRIEN, C.R.; KROCKENBERGER, M.B.; MARTIN, P.; WIGNEY, D.I., MALIK, R. Long-term outcome of therapy for 59 cats and 11 dogs with cryptococcosis. Australian Veterinary Journal, v. 84, p. 384-392, 2006.

PASSOS, A.N.; KOHARA, V.S.; FREITAS, R.S.; VICENTINI, A.P. Immunological assays employed for the elucidation of an histoplasmosis outbreak in São Paulo, SP

Brazilian Journal of Microbiology, v. 45, n. 4, p. 1357-1361, 2014.

POWERS, J.H. Considerations in clinical trials of combination antifungal therapy. Clinical Infectious Diseases, v. 39, n. 4, p. 228235, 2004 .

RAMDIAL, K.P.; MOSAM, A.; DLOVA, N.C.; SATAR, N.B.; ABOOBAKER, J.; SINGH, S.M. Disseminated cutaneous histoplasmosis in patients infected with human immunodeficiency virus. Journal of Cutaneous Pathology, v. 29, n.4), p. 215-225, 2002.

RASKIN, R.E. Skin and subcutaneous tissues. In: Raskin, R.E.; Meyer, D.J. Atlas of canine and feline cytology, $1^{\text {st }}$ ed. USA: W.B. Saunders Company, 2001. p. 50-51.

REINHART, J.M.; KUKANICH, K.S.; JACKSON, T.; HARKIN, K.R. Feline histoplasmosis: fluconazole therapy and identification of potential source of Histoplasma species exposure. Journal of Feline Medicine and Surgery, v. 14, n. 2, p. 841-848, 2012.

ROCHA-SILVA, F.; FIGUEIREDO, S.M.; SILVEIRA, T.T.S.; ASSUNÇÃO, C.B.; CAMPOLINA, S.S.; PENA-BARBOSA, J.P.P.; ROTONDO, A.; CALIGIORNE, R.B. Histoplasmosis outbreak in Tamboril cave - Minas Gerais state, Brazil. Medical Mycology Case Reports, v. 4, p. 1-4, 2014.

SCHUBACH, T.M.; SCHUBACH, A.; OKAMOTO, T.; BARROS, M.B.; FIGUEIREDO, F.B.; CUZZI, T.; FIALHO-MONTEIRO, P.C.; REIS, R.S.; PEREZ, M.A.; WANKE, B. Evaluation of an epidemic of sporotrichosis in cats: 347 cases (1998-2001). Journal of the American Veterinary Medical Association, v. 224, n.10, p. 16231629, 2004.

TABOADA, J. Systemic Mycoses. In: Ettinger, S.J.; Feldman, E.C. Textbook of Veterinary Internal Medicine - Diseases of the dog and cat, $5^{\text {th }}$ ed. California: W.B. Saunders Company, 2005. p. 453-465.

VINAYAK, A.; KERWIN, S.C.; POOL, R.R. Treatment of thoracolumbar spinal cord compression associated with Histoplasma capsulatum infection in a cat. Journal of the American Veterinary Medical Association, v. 7, p. 1018-1023, 2007.

ZANCOPÉ-OLIVEIRA, R.M.; MUNIZ, M.M.; VANKE, B. Histoplasmose. In: Coura, J.R. Dinâmica das doenças infecciosas e parasitárias. Rio de Janeiro: Guanabara Koogan, 2008, p. 1207-1221. 